\title{
EFFECTS OF Phoma herbarum AS A BIOLOGICAL CONTROL AGENT OF GLYPHOSATE RESISTANT Eleusine indica
}

\author{
RUSLI, M H ${ }^{1 *}$; SHARIFFAH MUZAIMAH, S A ${ }^{1}$; MAIZATUL, S M $^{1}$ and IDRIS, A S
}

\begin{abstract}
Goosegrass (Eleusine indica) is one of the weeds that has a problem of herbicide resistance to glyphosate. This study investigated the potential use of Phoma herbarum as a biological control agent of glyphosate resistant E. indica. Nursery and field experiments showed that the application of $10^{6}$ conidial suspension of $\mathrm{P}$. herbarum demonstrated biofungicidal activity whereby $91.7 \%$ of treated $\mathrm{E}$. indica died whilst for field experiment the mortality rate was recorded at $80 \%$. The effect of $\mathrm{P}$. herbarum was noticeable at 14 days after treatment and continued to increase at 21 days and 28 days after application. This study also investigated the direct effects of a few common herbicides that were used to control $\mathrm{E}$. indica in oil palm plantations. The study found that the P. herbarum was compatible with herbicide diuron and was able to cause $80 \%$ mortality to E. indica when diuron was applied at full strength. The percentage mortality of E. indica increased to $91.67 \%$ when half strength diuron was applied. Thus, this study was to report the effectiveness of $\mathrm{P}$. herbarum as a potential biological control agent against resistant $\mathrm{E}$. indica and compatible with herbicide diuron.
\end{abstract}

\section{Keywords: biological control, Eleusine indica, Phoma herbarum.}

Received: 18 February 2021; Accepted: 14 November 2021; Published online: 23 December 2021.

\section{INTRODUCTION}

Goosegrass (Eleusine indica) is a noxious weed in oil palm and fruit trees cultivations in Malaysia (Barnes and Chan, 1990). Eleusine is a member of the tribe Eragrosteae, family Poaceae (Bisht and Mukai, 2002). Goosegrass is an all-season prolific grass that is widely distributed in the tropics, particularly in Asia, Africa, South America, and the southern parts of North America (Holm et al., 1977). Eleusine indica was reported as one of the five most troublesome weeds in the world and caused problems to 46 different crop species in more than 60 countries (Chuah and Lim, 2015).

\footnotetext{
Malaysian Palm Oil Board, 6 Persiaran Institusi, Bandar Baru Bangi, 43000 Kajang, Selangor, Malaysia.
}

* Corresponding author e-mail: mohd.hefni@mpob.gov.my
In Malaysia, E. indica was found to be the most occurred grass $(82.2 \%)$ followed by Imperata cylindrical $(81.2 \%)$, Ishaemum muticum $(71.8 \%)$ and Pennisetum polystachion $(67.1 \%)$ in immature oil palm plantation (Maizatul-Suriza and Idris, 2012).

The only practical way to control E. indica is by using herbicide. However, excessive and repeated use of herbicide such as glyphosate to control $E$. indica has caused the weed to become resistant. Glyphosate resistance in E. indica has been reported in many countries and could seriously affect future control of this weed if the resistance problem is left unsolved (Chen et al., 2017; Lim and Ngim, 2000; Teng and Teo, 1999; Tran et al., 1999).

Due to the repeated use of herbicides with the same mode of action, populations of E. indica have evolved resistance to acetolactate synthase inhibitors (Valverde et al., 2000), acetyl CoA carboxylase inhibitors (Leach et al., 1995), bipyridiliums, glycines (Lim and Ngim, 2000), 
and dinitroaniline herbicides (Mudge et al., 1984), all of which are important herbicides for controlling $E$. indica in crops. In Malaysia, the first case of glyphosate-resistant annual grassy weed E. indica was reported in an orchard at Teluk Intan, Perak, Malaysia in 1998, where glyphosate failed to give adequate control of goosegrass in a four-year-old orchard (Lim and Ngim, 2000).

Thus, an alternative method such as using a biological control formulation, which is environmental-friendly for controlling weed species and reducing environmental pollution compared to using herbicide formulations that can affect soil microorganisms is sought after (Savita, 2019). Nevertheless, an effective microbial formulation plays a significant role in order to work as an alternative to chemical application (Lacey et al., 2001). Biological control of weeds is seen as an economical, effective and environmentally sound method of weed control. Many phytopathogenic fungi such as Fusarium oxysporum and Puccinia komarovii var. glanduliferae have been found to effectively control weeds (Currie et al., 2020; Dutta and Ray 2017).

Phoma herbarum Westend is an ubiquitous saprobe and toxigenic pathogen to plants and animals (Hamayun et al., 2009). Previous study has reported that three species of Phoma have been identified as potential biological control agents to various weeds (Harding and Raizada, 2015). Previous studies showed P. chenopodia could control weeds such as Chenopodium album, Cirsium arvense, Setaria viridis, and Mercurialis annua (Cimmino et al., 2013) whilst P. macrostoma was reported as biological control agent of many wide host range predominantly dicot plants (Bailey et al., 2011). Zhou et al. (2004) also isolated a number of $P$. macrostoma strains from necrotic lesions on Canada thistle [Cirsium arvense (L.) Scop.] plants collected from fields and roadside ditches.

It was reported that disease symptoms known as photobleaching whereby chlorosis and bleaching on the leaf tissues occurred on broadleaved weed species such as dandelion (Taraxacum officinale Weber ex F.H. Wigg.) when applied with mycelial fragments of P. macrostoma strain (Bailey et al., 2011). Todero et al. (2018) found out that culture filtrate of Phoma sp. showed significant phytotoxic efficiency against three weeds namely Bidens pilosa, Amaranthus retroflexus and Conyza canadensis when combined with specific adjuvants. Furthermore, Zhao and Shamoun (2005) reported that Phoma exigua can control salal (Gaultheria shallon), a perennial evergreen shrub.

Whilst, P. herbarum was reported as a biological control agent of dandelion weed Taraxacum officinale and Trianthema portulacastrum (Ray and Vijayachandran, 2013). P. herbarum also was reported to possess strong adaptability to diverse environments, including salty and chilly surroundings (Yang et al. 2005), and that it is also a versatile producer of many potent natural products (Cruz et al., 2003). To date, there is no report on the utilisation or application of $P$. herbarum as a biological control agent of E. indica. The potential of $P$. herbarum for biological control of weeds such as on turfgrass (Hahn et al., 2020) and other species of P. dimorpha on Echinochloa sp., Amaranthus cruentus, Senna obtusifolia and Bidens Pilosa (Neto et al., 2021) have made it as a promising candidate to control E. indica, consequently could be a key to solve the herbicide resistant problems in the field. Therefore, this study aimed to investigate $P$. herbarum as a potential biological control agent of resistant $E$. indica and its sequential application with herbicides.

\section{MATERIALS AND METHODS}

The resistant goosegrass seeds (Rusli et al., 2014) were collected from MPOB nursery in Section 15, Bandar Baru Bangi, Selangor, Malaysia and pre-germinated in trays containing a mixture of 3:2:1 (top soil: peat: sand) with a total weight of $3 \mathrm{~kg}$. After two weeks, the one seedling of goosegrass was transferred into each of the terracotta plant pots $(20 \times 8$ inches $)$. The soil medium was made up of sandy loam topsoil in a proportion of 2:1 (top soil: sand). Ten $g$ of rock phosphate was added to the soil medium in each pot to enhance and promote healthy plant growth and approximately $1.5 \mathrm{~kg}$ of soil medium was added to the pots, which were placed in the nursery with $50 \%$ polyethylene shading net. They were watered from below on alternate days. Other weeds were removed manually when necessary. Every month, approximately $5 \mathrm{~g}$ of N.P.K Green 15: 15: 15 (Nifosk Green) was applied to each pot.

\section{Preparation of $P$. herbarum (PH81) Inoculum}

Single spore isolates of $P$. herbarum (PH81) isolated from diseased E. indica from Malaysian Palm Oil Board (MPOB) nursery in Section 15, Bandar Baru Bangi, Selangor were used in the pathogenicity experiments. Isolates were stored at $-80^{\circ} \mathrm{C}$ in $20 \%$ glycerol and were then cultured on potato dextrose agar (PDA) and incubated at $28^{\circ} \mathrm{C}$ for five days. Three plugs of five-day-old fungus were inoculated onto solid media containing $50 \mathrm{~g}$ of semi-fine corns (0.1-0.2 cm), $1 \%$ starch, $1 \%$ sucrose and $30 \%$ water solutions (containing $0.01 \%$ Tween 20 and $0.1 \%$ glycerol). After 14 days of incubation at room temperature, the $P$. herbarum (PH81) spores were subjected to harvesting through filtration and counted using a haemocytometer. The $P$. herbarum (PH81) spore concentrations were adjusted to 106 conidia per $\mathrm{ml}$ upon spraying. 
Standard Inoculation Procedure for P. herbarum (PH81)

Ten $\mathrm{ml}$ of conidial suspension was applied to the leaves and around the base of each E. indica. The inoculated E. indica were watered with sterile distilled water (SDW) for two weeks. Un-inoculated E. indica served as controls. Eleusine indica seedlings were inoculated at one month of age.

\section{Colonisation of P. herbarum (PH81) on E. indica}

Re-isolation of $P$. herbarum (PH81) from the plant leaves and roots of each inoculated and uninoculated $E$. indica was attempted. For qualitative re-isolation, $3-\mathrm{cm}$ fragments of plant materials (leaves and roots) were surface sterilised in $2 \%$ $(\mathrm{v} / \mathrm{v})$ sodium hypochlorite for $10 \mathrm{~min}(5 \mathrm{~min}$ for tissue cores) before rinsing twice in SDW. The materials were then plated onto PDA and incubated for four days at $28^{\circ} \mathrm{C}$.

\section{Deoxyribonucleic Acid (DNA) Extraction}

Phoma herbarum (PH81) DNA was isolated using a modified cetyltrimethylammonium bromide (CTAB) method described by Manicom et al. (1987). First, $500 \mu \mathrm{L}$ of isolate suspension $\left(10^{6}\right.$ spores $/ \mathrm{mL}$ ) and 10-15 glass beads were vortexed in $1.5 \mathrm{~mL}$ Eppendorf tubes for $45 \mathrm{~s}$ to disrupt the cells. Then, $500 \mu \mathrm{L}$ of CTAB buffer $(2 \% \mathrm{w} / \mathrm{v}$ CTAB, $1 \mathrm{M}$ Tris-hydrochloric acid (Tris- $\mathrm{HCl}$ ) $\mathrm{pH} 8,5 \mathrm{M}$ sodium chloride $(\mathrm{NaCl})$ and $0.5 \mathrm{M}$ EDTA $\mathrm{pH} 8$ was added to the suspension and vortexed again before incubating the samples at $65^{\circ} \mathrm{C}$ for $40 \mathrm{~min}$. An equal volume of phenol: chloroform: isoamyl alcohol (25: 24: 1) was added to extract the DNA. The suspension was vortexed thoroughly to mix the layers and centrifuged at $4000 \mathrm{rpm}$ for $10 \mathrm{~min}$. The aqueous supernatant was transferred to a clean Eppendorf tube, and $500 \mu \mathrm{L}$ of cold isopropanol was added to precipitate nucleic acids overnight at $-20^{\circ} \mathrm{C}$. The DNA was pelleted at $13000 \mathrm{rpm}$ for $30 \mathrm{~min}$, washed with $100 \mu \mathrm{L}$ of cold $70 \%$ ethanol by centrifuging twice and taken up in $100 \mu \mathrm{L}$ of sterile MilliQ water. DNA purity and concentration were determined using the ND-100 Nanodrop Spectrophotometer (Thermo Scientific) according to the manufacturer's protocol.

\section{Polymerase Chain Reaction (PCR) for Target Sequence Amplification}

The PCR was performed with a PTC- $100^{\mathrm{TM}}(\mathrm{MJ}$ Research Cycling) in reaction volumes of $25 \mu \mathrm{L}$. Each reaction consisted of $>20 \mathrm{ng}$ genomic DNA (or a $2.5 \mu \mathrm{L}$ culture suspension), $0.2 \mu \mathrm{M}$ of each primer, $0.4 \mathrm{mM}$ dNTP mix (10 mM, Promega), 0.5× GoTaq buffer (5× GoTaq buffer, Promega), $2.5 \mathrm{mM} \mathrm{MgCl}{ }_{2}$
(25 mM, Promega), $0.02 \mathrm{u} / \mu \mathrm{L}$ GoTaq $^{\circledR}$ DNA polymerase (5 $\mathrm{u} / \mu \mathrm{L}$, Promega), and sterile Milli-Q water. The PCR cycle conditions were as follows: one cycle at $94^{\circ} \mathrm{C}$ for $5 \mathrm{~min}$, followed by 40 amplification cycles at $94^{\circ} \mathrm{C}$ for $0.05 \mathrm{~s}, 57^{\circ} \mathrm{C}$ for $0.05 \mathrm{~s}$, and $72^{\circ} \mathrm{C}$ for $0.05 \mathrm{~s}$. A final extension at $72^{\circ} \mathrm{C}$ for $2 \mathrm{~min}$ was done after 40 cycles followed by cooling at $14^{\circ} \mathrm{C}$ until recovery of the sample. Amplification products were assessed on a $1 \% \mathrm{w} / \mathrm{v}$ agarose gel stained with ethidium bromide run for $20 \mathrm{~min}$ at 80 volts and visualised under ultraviolet (UV) illumination.

\section{Nursery Trial}

The nursery trial was carried out in Bandar Baru Bangi, Selangor, Malaysia (2 57' 56.4120" N and $101^{\circ} 45^{\prime} 3.2688^{\prime \prime} \mathrm{E}$ ). The experiment comprised of two treatments (treated and untreated) carried out where each treatment consisted of 20 pots with three replicates using a randomised complete block design (RCBD). Each plant was inoculated with $10 \mathrm{ml}$ of $3 \times 10^{6}$ P. herbarum (PH81) conidia $/ \mathrm{ml}$. The determinations of weed mortality were carried out at 7, 14, 21 and 28 days post-inoculation, and sample re-isolation was performed at the end of the experiment, after 28 days.

\section{Field Trial}

A field trial was conducted in Bandar Baru Bangi, Selangor, Malaysia ( $2^{\circ} 57^{\prime} 56.4120^{\prime \prime} \mathrm{N}$ and $\left.101^{\circ} 45^{\prime} 3.2688^{\prime \prime} \mathrm{E}\right)$. This experiment made use of the available $E$. indica to simulate the real weed conditions in the field. It was set up in plots $(2 \mathrm{~m} \times$ $5 \mathrm{~m}$ ) with approximately $20 \mathrm{E}$. indica aged between 1-2 months old (based on the last cycle of herbicide application) in each plot. Two treatments were replicated in five $R C B D$ plots whereby the first treatment consisted of $200 \mathrm{~mL}$ of $10^{6} \mathrm{P}$. herbarum (PH81) conidial/mL suspensions sprayed in each plot using a hand-operated sprayer (a knapsack hand pump) with a cone (green) nozzle and the second treatment was a control plot (E. indica sprayed with water). The determinations of weed mortality were carried out at 7, 14, 21, 28 and 35 days post-inoculation and $P$. herbarum (PH81) sample re-isolation was performed at the end of the experiment after 35 days.

\section{The Percentage of Weed Mortality in Nursery and Field Trials}

The weed mortality percentage was taken at one, two, three and four weeks after treatment (WAT) by counting plants with all tissues completely dead from the point of growing to the surface of soil using a non-destructive sampling method. 


\section{Eleuisine indica Dry Weight}

The growth parameters and dry weight were assessed. The weeds planted in the pots were washed twice with tap water before constant dry weight $(\mathrm{g})$ of the whole plant (roots and aerial parts) were determined, following $\geq 72 \mathrm{hr}$ at $80^{\circ} \mathrm{C}$ in a drying oven (Rusli et al., 2014).

\section{Sequential Application of Herbicide and Bioherbicide on Goosegrass Mortality}

The experiment was conducted in an open nursery area in Bandar Baru Bangi, Selangor, Malaysia ( $2^{\circ} 57^{\prime} 56.4120^{\prime \prime} \mathrm{N}$ and $101^{\circ} 45^{\prime} 3.2688^{\prime \prime}$ E). Five commonly used herbicides to control E. indica and a stock solution of each herbicide was made based the product's field recommendation (Table 1). Each treatment consisted of 20 pots with three replicates using a RCBD. Each plant was inoculated with $10 \mathrm{ml}$ of $3 \times 10^{6}$ P. herbarum (PH81) conidia/mL, $12 \mathrm{hr}$ after application of herbicide at full strength and half strength. The determinations of weed mortality were carried out at 7, 14, 21 and 28 days post-inoculation.

\section{Statistical Analysis}

The data collected in the nursery and field studies were subjected to Fisher's exact test. Means were separated using a significance level of $p<0.05$. Comparisons between the treatment means were made using Tukey's HSD test.

\section{RESULTS}

Efficacy of $P$. herbarum (PH81) on E. indica in the Nursery Trial

Based on the nursery trials, the effects of P. herbarum (PH81) application were noticeable after 14 days with $30 \%$ mortality and continued to increase significantly with mortality rate at $80 \%$ after 21 days post application. It was noticeable that formation of $P$. herbarum (PH81) mycelia on the treated E. indica leaves. Overtime, it was observed that $P$. herbarum (PH81) incite photobleaching on the infected leaves and gradually became chlorotic before eventually die (Figure 1). The same symptoms was observed when Conyza canadensis was treated with mycoherbicides derived from Phoma sp. (Todero et al., 2018). At the end of the experiment, $90 \%$ of the E. indica treated with P. herbarum (PH81) was dead 28 days after treatment, whereas no dead signs were observed in the control treatment during the same period (Table 2). Twenty fungal isolations from samples that showed black spot discolourations and dried and colonised roots of E. indica were carried out at the end of the experiment. The samples were subjected to PCR amplifications using universal primers (White et al., 1990) and were sent out for sequence analysis. Based on the Basic Local Alignment Search Tool (BLAST) sequence analysis, it was found that the isolated fungus was P. herbarum. This showed that a stable formulation of $P$. herbarum that can sustain the viability of a potential biocontrol agent has been developed and can be delivered to the target weed.

\section{Field Efficacy Test of $P$. herbarum (PH81) on E. indica}

Seven days after treatment, no mortality was observed in all treated quadrats. However, the mortality of E. indica increased significantly 14 days after treatment to $30 \%$ (Table 3). The mortality pattern was similar to the previous nursery trial. It was also observed that from day 14 to day 21, a sharp trend of E. indica mortality was recorded whereby the percentage of mortality jumped from 30\%-70\%. The mortality rate of $E$. indica continued until 28 days and stabilised at $80 \%$ (Table 3 ). This shows that E. indica are susceptibleto P.herbarum(PH81)infections. Thetreated E. indica showed black spot discolourations and dried in all quadrats. These are typical symptoms of Phoma infections which range from necrotic spots, chlorotic halos and wilting (Deb et al., 2020). The study also

TABLE 1. SELECTION OF HERBICIDES WITH DIFFERENT ACTIVE INGREDIENTS
AND MODE OF ACTIONS USED IN EXPERIMENTAL STUDIES


TABLE 2. PERCENTAGE OF Eleusine indica MORTALITY DUE TO Phoma herbarum (PH81) INFECTION AT 7, 14, 21 AND 28 DAYS AFTER TREATMENT IN NURSERY TRIAL

\begin{tabular}{lccc}
\hline Treatment & \multicolumn{2}{c}{ of dead E. indica } \\
\cline { 2 - 4 } & 7 days & 14 days & 21 days \\
$\begin{array}{l}\text { T1 }- \text { E. indica treated with P. herbarum }(\mathrm{PH} 81) \\
\left(10^{6} \text { conidia } / \mathrm{mL}\right)\end{array}$ & $0 \mathrm{a}$ & $30 \mathrm{a}$ & $90 \mathrm{a}$ \\
$\mathrm{T} 2-$ Untreated . indica (control) & $0 \mathrm{a}$ & $0 \mathrm{~b}$ & $0 \mathrm{~b}$ \\
\hline
\end{tabular}

Note: Different letters denote a significance $(p<0.05)$ between different treatments on $E$. indica analysed by Fisher's exact test. $\mathrm{n}-20$; replicate - 3; experimental design - RCBD.

TABLE 3. THE EFFICACY OF Phoma herbarum (PH81) ON RESISTANT Eleusine indica IN A FIELD TRIAL

\begin{tabular}{|c|c|c|c|c|c|}
\hline \multirow[t]{2}{*}{ Treatment } & \multicolumn{5}{|c|}{ Mortality of E. indica (\%) } \\
\hline & 7 days & 14 days & 21 days & 28 days & 35 days \\
\hline $\mathrm{T} 1-$ P. herbarum $(\mathrm{PH} 81)$ at $10^{6}$ conidial $/ \mathrm{mL}$ & 0 & $30 \mathrm{a}$ & $70 \mathrm{a}$ & & $80 \mathrm{a}$ \\
\hline T2 - Untreated E. indica (control) & 0 & $0 b$ & $0 b$ & $\mathrm{Ob}$ & $10 b$ \\
\hline
\end{tabular}

Note: Different letters denote a significance $(p<0.05)$ between different treatments on E. indica analysed by Fisher's exact test. $\mathrm{n}$ - 5 ; replicate - 3; experimental design - RCBD.
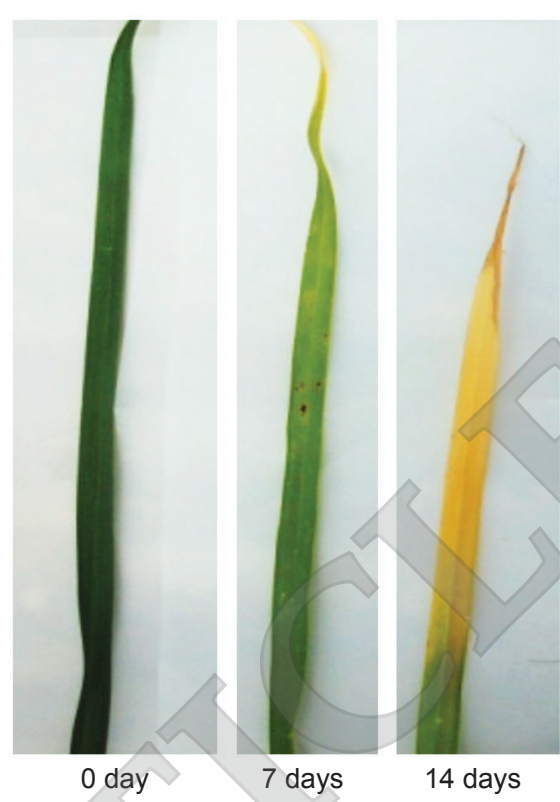

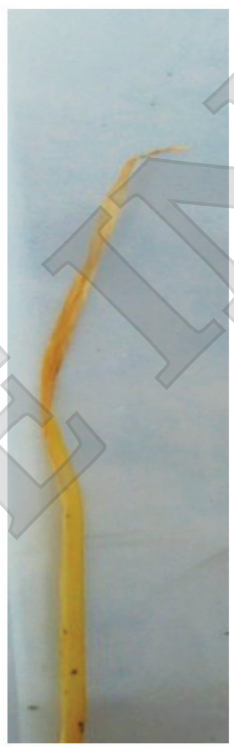

21 days

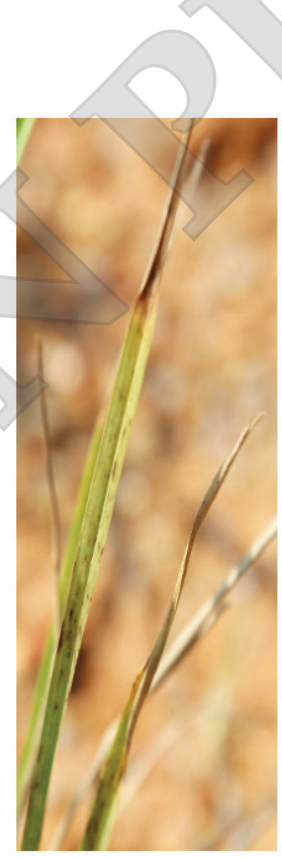

28 days

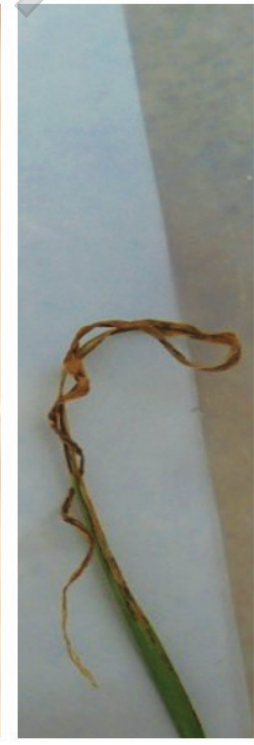

35 days

Figure 1. The photobleaching and chlorosis effects of P. herbarum application at seven days interval in field trial.

recorded that $10 \%$ of the untreated E. indica died due to ageing factors. Further investigation found that the weed's root system were still active and regenerated after 42 days post treatments in all quadrat. Figliola et al. (1988) also reported similar findings when two leaf-spotting pathogens, Bipolaris setariae (Saw.) and Pyricularia grisea (Cke.) Sacc., were applied to E. indica. In comparison, E. indica regeneration was recorded 21 days after treatment when conventional herbicide mixtures were used (Rusli et al., 2014).

This experiment exhibited significantly reduced dry weight compared to the control treatment as shown in Table 4. Field efficacy treatments of $P$. herbarum as a potential biological control agent on E. indica have been repeated on a number of occasions
TABLE 4. THE EFFECT OF Phoma herbarum (PH81) TREATMENT ON Eleusine indica DRY WEIGHT 35 DAYS AFTER APPLICATIONS

\begin{tabular}{lc}
\hline Treatment & Dry weight (g) \\
\hline $\mathrm{T} 1-$ P. herbarum $\left(\mathrm{PH} 81\right.$ ) at $10^{6}$ conidial $/ \mathrm{mL}$ & $115 \mathrm{a}$ \\
$\mathrm{T} 2$ - Untreated E. indica (control) & $250 \mathrm{~b}$ \\
\hline
\end{tabular}

Note: Different letters denote a significance $(p<0.05)$ between different treatments on E. indica analysed by Fisher's exact test. $\mathrm{n}$ - 5; replicate - 3; experimental design - RCBD.

and giving similar results. The effectiveness of $P$. herbarum treatment indicated the fungus is a potential biological control agent whereby it could suppress the weed growth compared to control. 


\section{Sequential Herbicide Application and Bioherbicide (PH81) on Goosegrass}

The bio herbicide fungus, $P$. herbarum (PH81) was tested alone and $12 \mathrm{hr}$ after full strength or half strength selected herbicides application. Based on the results obtained, treatment with $P$. herbarum (PH81) and full strength gluphosinate ammonium (T4) recorded the highest $E$. indica mortality as early as seven days post application (Table 5). The weed mortality continued to increase at day $14(93.33 \%)$, day $21(98.33 \%)$ and day $28(100 \%)$. Treatment of P. herbarum (PH81) with half strength gluphosinate ammonium recorded a lower mortality rate at $43.33 \%$ during the whole course of the experiment. The treated E. indica was then sampled and fungal re-isolation was carried out in order to confirm the presence of $P$. herbarum (PH81). Nevertheless, no $P$. herbarum can be re-isolated from E. indica in T4.

It was also recorded that the E. indica mortality in T3 also high with treatment $P$. herbarum (PH81) and full strength diuron shows $71.67 \%$ mortality after seven days post application before stagnated at $80 \%$. However, treatment $P$. herbarum (PH81) and half strength diuron killed $50 \%$ of treated E. indica and the mortality rate increased to $60 \%$ (day 14) and $91.67 \%$ at day 21 dan 28. This was the highest percentage of mortality recorded compared to other treatments. Based on fungal re-isolation and sequence analysis, the presence of $P$. herbarum (PH81) was identified and confirmed. It was recorded that, weed mortality was significantly improved when P. herbarum (PH81) was applied with reduced diuron rate.

For T5, no P. herbarum could be re-isolated from treatment with paraquat although $80 \%$ weed killed was achieved with full strength paraquat application. This could probably due to the herbicide toxicity that inhibited or killed P. herbarum (PH81). Nevertheless, P. herbarum (PH81) could be isolated from T1 and T2 when the herbicides were applied at half strength though the percentage of mortality were low. T1 recorded weed mortality at $11.67 \%$ at full strength glyphosate isopropylammonium in combination with P. herbarum (PH81) while half strength application recorded weed mortality at $28.33 \%$. T2 also showed low weed control whereby full strength application of glyphosate monoammonium with $P$. herbarum (PH81) only showed 20\% mortality whilst $10 \%$ weed mortality was recorded with half strength application of the herbicide. Treatment with full strength P. herbarum (PH81) (T6) showed similar pattern as observed in previous field trial whereby $28.33 \%$ E. indica mortality due to PH81 infection was recorded. The highest E. indica mortality rate was recorded at 21 days post inoculation at $80 \%$ and maintained when assessment was carried out at 28 days. Nevertheless, half strength application of PH81 was only able to kill $50 \%$ of the resistant $E$. indica.

TABLE 5. BIOHERBICIDAL ACTIVITY OF P. herbarum (PH81) IN COMBINATION WITH FULL STRENGTH AND HALF STRENGTH OF SELECTED HERBICIDES AGAINST E. indica

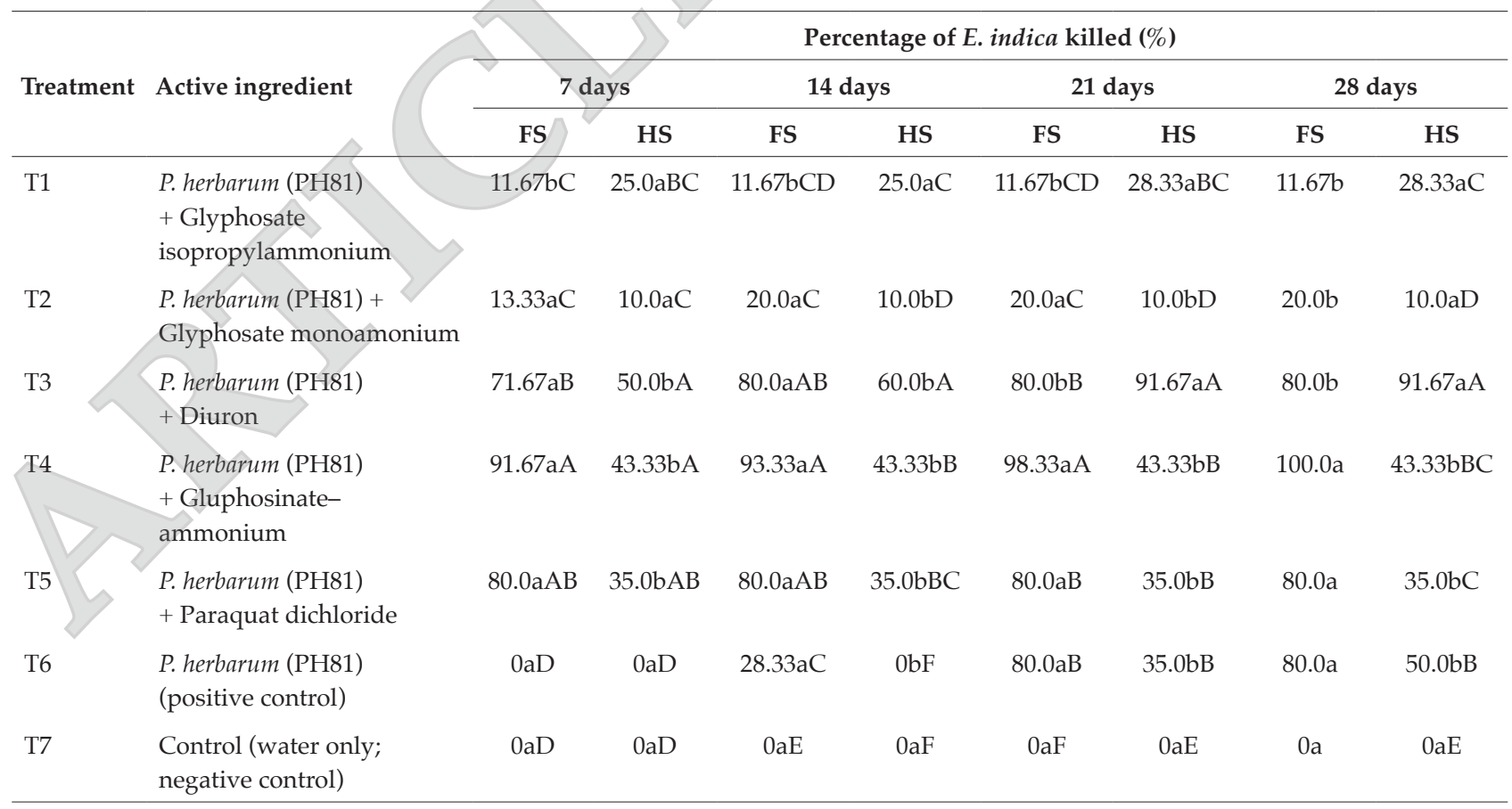

Note: *FS - Full strength of herbicide rate application; HS - Half strength of herbicide rate application. Different lowercase letters denote a significance $(p<0.05)$ between different treatments strength of each herbicides (between columns) and between treatment (between rows) on E. indica analysed by Fisher's exact test. Different uppercase letters denote a significance $(p<0.05)$ between treatment 1 to treatment 6 by Fisher's exact test. $n$ - 20; replicate - 3; experimental design - RCBD. 


\section{DISCUSSION AND CONCLUSION}

Chemical control represents an effective way to control weeds for many decades. In Malaysia, the agriculture sectors remains reliant on herbicides despite some efforts to integrate with physical, mechanical and biological methods (Dilipkumar et al., 2020). The heavy dependence to herbicides has affected the environment, people, animal and furthermore causing weeds to evolve and become resistant; hence higher use rate is needed for control.

In this study, a stable formulation of $P$. herbarum (PH81) that is able to sustain the viability of potential biocontrol agent and can be delivered to the target weed has been developed for both nursery and field applications. According to the nursery trials, P. herbarum (PH81) showed an effective potential as a biological agent to control goosegrass (E. indica) with $91.7 \%$ efficacy while the mortality rate of E. indica recorded in the field trials was $80 \%$ and recorded the lowest dry weight which showed the effectiveness of the treatment. It is interesting to note that wild E. indica around the field trial was reported to be resistant to glyphosate (Rusli et al., 2014). This suggested that application of $P$. herbarum (PH81) could be a feasible alternative to control glyphosate resistant $E$. indica.

For both the nursery and field trials, the infection began 14 days after $P$. herbarum application. This result agrees with that of Bailey et al. (2011), who also recorded Phoma sp. colonisation and mycelial growth on the epidermis of barley roots and root hair seven days and 28 days after treatment, respectively. Phoma sp. was recently reported to significantly reduced verticillium wilt of olive disease severity caused by Verticillium dahlia 12 weeks post application (Ana López-Moral et al., 2021).

Hynes (2018) stated that the ubiquitous genus of Phoma had been widely reported as the fungus that was responsible for saprophytic, phytopathogenic and recently bio herbicidal activity, therefore it was not surprising that the P. herbarum could also control resistant $E$. indica. This is the first report of $P$. herbarum as a potential biological control agent of resistant E. indica. Vikrant et al. (2006) identified one particular toxin 3-nitro-1,2-benzenedi-carboxylic acid (3-natrophthalic acid) from $P$. herbarum that can be applied as a phytotoxin against target weed Parthenium hysterophorus.

Phoma species have also previously been linked as biological control agents for many invasive weeds such as Canada thistle (Guske et al., 2004), and dandelion (Neumann and Boland, 2002). This study recorded that photo-bleaching and chlorosis symptoms appeared 14 days after inoculation. Similarly, Hynes (2018) reported that Phoma sp. causes photo-bleaching, significantly reduced the overall weed biomass and weed death whilst Johnston (1981) reported root inhibition by Phoma sp. in susceptible plants when broadcast onto the soil as granules.

The delivery of the product formulation of $P$. herbarum through soil application further enhanced its ability to infect the target weed. Pedrasand Yu (2008) stated that Phoma affected the target weed by secreting macrocidins that was able to deteriorate the weed's cortex. The application of the fungus at or below soil surface was also found effective and thought to overcome environment detrimental caused by the application of foliar bioherbicides (Boyette et al.,1991); the persistent and survival of the biological agent was also found to be increased and therefore provide longer term weed control (Boyette et al., 1984). Previous study also reported that soil application of $P$. macrostoma's mycelium was more effective in controlling dandelion compared to using its spores (Bailey et al., 2011).

Nevertheless, it is important to note that many of the previous bioherbicides restricted in their use (Jones and Hancock, 1990). Host range studies have shown that the use of Phoma sp. as bioherbicide affects several plant species in the Asteraceae, Brassicaceae, and Leguminosae (Bailey et al., 2011). Hynes (2018) continued to report that no Phoma spp. infection was observed on species from the plant families Poaceae, Pinaceae and Lamiaceae, such as Agrostis palustris (bentgrass), Poa pratensis (Kentucky bluegrass), Picea mariana (black spruce), Pinus spp. (pine), Salvia coccinea (Crimson sage). Bailey et al. (2009) stated that it was vital to demonstrate that the potential bioherbicide does not pose risk to nontarget species particularly in the surrounding area of the targeted weeds. It is important to note that P. herbarum (PH81) was also inoculated on various crops such as oil palm, maize, chilli and okra and the study (unpublished) found that no infection occurred on these crops that are usually used in oil palm integration.

The incompatibility between mycoherbicide and chemical herbicides is still under study, but herbicides are known to interfere with disease development, either because of a direct toxicity to the pathogen or indirectly by triggering defence responses in the plants (Sanogo et al., 2000). The negative effect of gluphosinate ammonium, paraquat dichloride, glyphosate isopropylammonium and glyphosate monoammonium towards $P$. herbarum showed that herbicides can inhibit disease progress because of their direct toxicity to the fungus. Therefore, it is not recommended to use these herbicides in combination with the application of $P$. herbarum since the herbicides will have a tendency to kill the fungus. Moreover, in the field, the fungus exists as a weak, opportunistic, or wound pathogen occurring mostly on woody hosts, especially on members of the Rosaceae (Farr et al., 1989). However, the combination of $P$. herbarum with diuron could yield encouraging results for the potential of fungus- 
herbicide combinations. Nevertheless, a field trial needs to be conducted to verify this assumption about fungus-herbicide combinations.

Lastly, it was also noted that the application of $P$. herbarum was effective when weeds were at the pre-emergence stages, then it became difficult to control over time as the weeds become persistent and well established. Indeed, one of the most important aspects for successful biocontrol is an even distribution of the bioherbicides. Therefore, the application of bioherbicide at the pre-emergence stages is crucial and essential in order to control this noxious weed.

\section{ACKNOWLEDGEMENT}

This research was supported by the Malaysian Palm Oil Board (MPOB). We thank many colleagues at MPOB for providing the materials for this study. This work was conducted at the Malaysian Palm Oil Board headquarters in Bandar Baru Bangi, Selangor, Malaysia.

\section{REFERENCES}

Ana López-Moral, A; Agustí-Brisach, C and Trapero, A (2021). Plant biostimulants: New insights into the biological control of verticillium wilt of olive. Front. Plant Sci., 2: 662178. DOI: 10.3389/fpls.2021.662178.

Bailey, K L; Boyetchko, S M; Peng, G; Hynes, R K; Taylor, W G and Pitt, W M (2009). Developing weed control technologies with fungi. Current Advances in Fungal Biotechnology (Rai, M ed.). I.K. International Pvt. Ltd., New Delhi, India. p. 1-44.

Bailey, K L; Pitt, W M; Falk, S and Derby, J (2011). The effects of Phoma macrostoma on non-target plant and target weed species. Biol. Control, 58: 379-386. DOI: 10.1016/j.biocontrol.2011.06.001.

Barnes, D E and Chan, L G (1990). Common Weeds of Malaysia and Their Control. Ancom Berhad. Kuala Lumpur, Malaysia. 349 pp.

Bisht, M S and Mukai, Y (2002). Genome organization and polyploid evolution in the genus Eleusine (Poaceae). Plant Syst. Evol., 233: 243-258. DOI: 10.1007 / s00606-002-0201-5.

Boyette, C D; Templeton, G E and Oliver, L R (1984). Texas gourd (Cucurbita texana) control with Fusarium solani f.sp.cucurbitae. Weed Sci., 32: 649657. DOI: 10.1017 / S0043174500059737.

Boyette, C D; Quimby, JR P C; Connick, JR W J; Daigle, D J and Fulgham, F E (1991). Progress in the production, formulation and application of mycoherbicides. Microbial Control of Weeds (TeBeest, D O ed.). Chapman and Hall Inc., New York. p. 209224.

Chen, J; Huang, H; Wei, S; Huang, Z; Wang, X and Zhang, C (2017). Investigating the mechanism of glyphosate (Eleusine indica (L.) Gaertn.) by RNA sequencing technology. Plant J., 89: 407-415. DOI: 10.1111 / tpj.13395.

Chuah, T S and Lim, W K (2015). Assessment of phytotoxic potential of oil palm leaflet, rachis and frond extracts and powders on goosegrass [Eleusine indica (L.) Gaertn.] germination, emergence and seedling growth. Malays. Appl. Biol., 44: 75-84.

Cimmino, A; Andolfi, A; Zonno, M C; Avolio, F; Santini, A; Tuzi, A; Berestetskyi, A; Vurro, M and Antonio, E (2013). Chenopodolin: A phytotoxic unrearranged ent-pimaradienediterpene produced by Phoma chenopodicola, a fungal pathogen for Chenopodium album biocontrol. J. Nat. Prod., 76: 1291-1297. DOI: $10.1021 / \mathrm{np} 400218 \mathrm{z}$.

Cruz, J F R; Macias, M; Rojas, C M C G and Mata, R (2003). A new phytotoxic nonenolide from Phoma herbarum. J. Nat. Prod., 66: 511-514. DOI: 10.1021/ np020501t.

Currie, A F; Gange, A C; Ab Razak, N; Ellison, C A; Maczey, N and Wood, S V (2020). Endophytic fungi in the invasive weed Impatiens glandulifera: A barrier to classical biological control? Weed Res., 60: 50-59. DOI: 10.1111/wre.12396.

Deb, D; Khan, A and Dey, N (2020). Phoma diseases: Epidemiology and control. Plant Pathol., 69: 12031217. DOI: 10.1111 / ppa.13221.

Dilipkumar, M; Chuah, T S; Hoh, S H and Sahid, I (2020). Weed management issues, challenges and opportunities in Malaysia. Crop Prot., 134: 104347. DOI: $10.1016 /$ j.cropro.2017.08.027.

Dutta, W and Ray, P (2017). A glimpse into the compatibilities and conflicts between arthrods and fungal biological control agents of aquatic weed waterhyacinth. Phytoparasitica, 45: 429-437. DOI: 10.1007 / s12600-017-0605-y.

Farr, D F; Bills, G F; Chamuris, G P and Rossman, A Y (1989). Fungi on Plants and Plant Products in the United States. VIII, 1252 S. The American Phytopathological Society (APS) Press, St. Paul, Minnesota. DOI: 10.1002/ fedr.19901010703.

Figliola, S S; Camper, N D and Ridings, W H (1988). Potential biological control agents for goosegrass 
Eleusine indica. Weed Sci., 36: 830-835. DOI: 10.1017/ S0043174500075913.

Guske, S; Schulz, B and Boyle, C (2004). Biocontrol options for Cirsium arvense with indigenous fungal pathogens. Weed Res., 44: 107-116. DOI: $10.1111 /$ j.1365-3180.2003.00378.x.

Hamayun, M; Khan, S A; Khan, A L; Rehman, G; Sohn, E-Y; Shah, A A; Kim, S-K; Joo, G-J and Lee, I-J (2009). Phoma herbarum as new gibberellinproducing and plant growth promoting fungus. J. Microbiol. Biotech., 19: 1224-1249. DOI: 10.4014/ jmb.0901.030.

Harding, D P and Raizada, M N (2015). Controlling weeds with fungi, bacteria and viruses: A review. Front. Plant Sci., 6: 659. DOI: 10.3389/ fpls.2015.00659.

Hahn, D; Sallenave, R; Pornaro, C and Leinauer, B (2020). Managing cool-season turfgrass without herbicides: Optimizing maintenance practices to control weeds. Crop Sci., 60: 2204-2220. DOI: $10.1002 / \csc 2.20175$.

Hynes, R K (2018). Phoma macrostoma: As a broad spectrum bioherbicide for turfgrass and agricultural applications. $C A B$ Reviews, 13: 5. DOI: 10.1079/ PAVSNNR201813005.

Holm, L G; Plucknett, D L; Pancho, J V and Herberner, J P (1977). The World's Worst Weeds. University Press of Hawaii, Honolulu. 609 pp.

Jones, R W and Hancock, J G (1990). Soilborne fungi for biological control of weeds. Microbes and Microbial Products as Herbicides (Hoagland, R E ed.). ACS Symposium Series, Vol. 439. American Chemical Society, Washington, DC. p. 276-286.

Johnston, P R (1981). Phoma on New Zealand grasses and pasture legumes. N. Z. J. Bot., 19: 173186. DOI: $10.1080 / 0028825 X .1981 .10425118$.

Lacey, L A; Frutos, R; Kaya, H K and Vail, P (2001). Insect pathogens as biological control agents: Do they have a future? Biol. Control, 21: 230-248. DOI: 10.1006/bcon.2001.0938.

Leach, G E; Devine, M D; Kirkwood, R C and Marshall, G (1995). Target enzyme-based resistance to acetyl-coenzyme A carboxylase in-hibitors in Eleusine indica. Pestic. Biochem. Phys., 51: 129-136. DOI: $10.1006 /$ pest.1995.1013.

Lee, L J and Ngim, J (2000). A first report of glyphosate-resistant goosegrass [Eleusine indica (L.) Gaertn] in Malaysia. Pest Manag. Sci., 56:
336-339. DOI: 10.1002/(SICI)1526-4998(200004) 56:4<336::AID-PS123>3.0.CO;2-8.

Maizatul-Suriza, M and Idris, A S (2012). Occurrence of common weeds in mature plantings of oil palm plantations in Malaysia. The Planter, 88: 537-547.

Manicom, B Q; Bar-Joseph, M; Rosner, A; Vigodsky-Haas, H and Kotze, J M (1987). Potential applications of random DNA probes and restriction fragment length polymorphisms in the taxonomy of the Fusaria. Phytopathology, 77: 669-672. DOI: 10.1094/Phyto-77-669.

Mudge, L C; Gosset, T B J and Murphy, T R (1984). Resistance of goosegrass (Eleusine indica) to dinitroaniline herbicides. Weed Sci., 32: 591-594. DOI: $10.1017 /$ S0043174500059610.

Neumann, S and Boland, G J (2002). Influence of host and pathogen variables on the efficacy of Phoma herbarum, a potential biological control agent of Taraxacum officinale. Can. J. Bot., 80: 425-429. DOI: $10.1139 /$ b02-024.

Neto, J R C; dos Santos, M S N; Mazutti, M A; Zabot, G L and Tres, M V (2021). Phoma dimorpha phytotoxic activity potentialization of bioherbicide production. Biocatal. Agric. Biotechnol., 33: 101986. DOI: 10.1016/j.bcab.2021.101986.

Pedras, M S C and Yu, Y (2008). Structural and biological activity of maculansin A, a phytotoxin from the phytopathogenic fungus Leptosphaeria maculans. Phytopathol, 69: 2966-2971. DOI: 10.1016/j. phytochem.2008.09.015.

Ray, P and Vijayachandran, LS (2013). Evaluation of indigenous fungal pathogens from horse purslane (Trianthema portulacastrum) for their relative virulence and host range assessments to select a potential mycoherbicidal agent. Weed Sci., 61: 580585. DOI: 10.1614/WS-D-12-00076.1.

Rusli, M H; Idris, A S; Norman, K and Sim, K C (2014). The combination effect of MSMA and Diuron in controlling glyphosate resistant Eleusine indica in oil palm plantation. The Planter, 90: 801815.

Sanogo, S; Yang, X B and Scherm, H (2000). Effects of herbicides on Fusarium solani f.sp. glycines and development of sudden death syndrome in glyphosate-tolerant soybean. Phytopathology, 90: 57-66. DOI: 10.1094/ PHYTO.2000.90.1.57.

Savita, S A (2019). Fungi as biological control agents. Biofertilizers for Sustainable Agriculture and 
Environment (Giri, B; Prasad, R; Wu, Q S and Varma, A eds.). Soil Biology Springer, Cham. 55 pp. DOI: 10.1007 / 978-3-030-18933-4.

Teng, Y T and Teo, K C (1999). Weed control and management of resistant goose grass (Eleusine indica) in Malaysia. Proc. of the $17^{\text {th }}$ Asian-Pacific Weed Science Society Conference. 22-27 November 1999. Bangkok, Thailand. p. 753-758.

Todero, I; Confortin, T C; Luft, L; Brun, T; Ugalde, G A; De Almeida, T C; Arnemann, J A; Zabot, G L and Mazutti, M A (2018). Formulation of a bioherbicide with metabolite from Phoma sp. Sci. Hortic., 241: 285-292. DOI: 10.1016/j.scienta.2018.07.009.

Tran, M; Baerson, S; Brinkler, R; Casagrande, L; Falletti, M and Feng, Y (1999). Characterization of glyphosate resistant Eleusine indica biotypes from Malaysia. Proc. of the $17^{\text {th }}$ Asian-Pacific Weed Science Society Conference. 22-27 November 1999. Bangkok, Thailand. p. 527-536.

Valverde, B E; Riches, C R and Caseley, J C (2000). Prevention and Management of Herbicide Resistant Weed in Rice: Experiances from Central America with Echinochloa colona. Camara de Insumos Agropecuarios, Costa Rica's. http:/ / www. weedscience.org / EBooks / RiceBookIntro. aspx., accessed on 1 May 2020.
Vikrant, P; Verma, K K; Rajak, R C and Pandey, A K (2006). Characterization of a phytotoxin from Phoma herbarum for management of Parthenium hysterophorus L. J. Phytopathol.,154: 461-468. DOI: 10.1111/j.1439-0434.2006.01129.x.

White, T J; Bruns, T; Lee, S and Taylor, J W (1990). Amplification and direct sequencing of fungal ribosomal RNA genes for phylogenetics. PCR protocols. A Guide to Methods and Applications (Innis, M A; Gelfand, D H; Sninsky, J J and White, T Jeds.). Academic Press, San Diego, CA, USA. p. 315-322.

Yang, X B; Gao, X D; Han, F B and Tan, R X (2005). Sulfation of a polysaccharide produced by a marine filamentous fungus Phoma herbarum (YS4108) alters its antioxidant properties in vitro. Biochim Biophys Acta, 1725: 120-127. DOI: 10.1016/j. bbagen.2005.06.013.

Zhou, L; Bailey, K L and Derby, J (2004). Plant colonization and environmental fate of the biocontrol fungus Phoma macrostoma. Biol. Control, 30: 634-644. DOI: 10.1016/j.biocontrol.2004.03.002.

Zhao, S and Shamoun, S F (2005). Effects of potato dextrose broth and gelatin on germination and efficacy of Phoma exigua, a potential biocontrol agent for salal (Gaultheria shallon). Can. J. Plant Pathol., 27: 234-244. DOI: 10.1080 / 07060660509507221. 